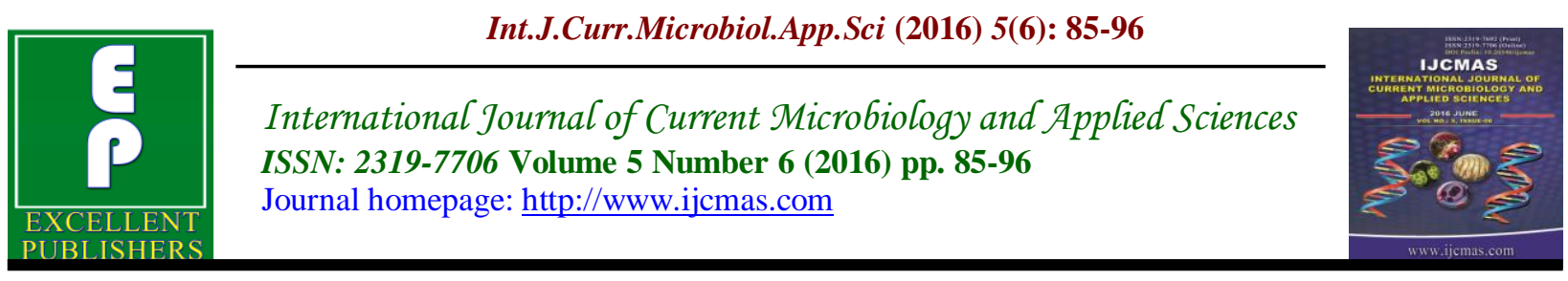

Review Article

http://dx.doi.org/10.20546/ijcmas.2016.506.011

\title{
Role of Potyviruses in Synergistic Interaction Leading to Maize Lethal Necrotic Disease on Maize
}

\author{
E.R. Mbega ${ }^{1 *}$, P.A. Ndakidemi ${ }^{1}$, D.P. Mamiro $^{2}$, A.A. Mushongi ${ }^{3}$, \\ K.M. Kitenge ${ }^{4}$ and O.A. Ndomba ${ }^{5}$ \\ ${ }^{1}$ Nelson Mandela-AIST, PO Box 447, Arusha, Tanzania \\ ${ }^{2}$ Sokoine University of Agriculture, P.O. BOX 3000, Chuo Kikuu, Morogoro, Tanzania \\ ${ }^{3}$ Agricultural Research Institute - Uyole, P.O. BOX 600, Mbeya Tanzania \\ ${ }^{4}$ Selian Agricultural Research Institute, P.O. Box 6024, Arusha Tanzania \\ ${ }^{5}$ Tropical Pesticide Research Institute, PO Box 3024, Arusha Tanzania \\ *Corresponding author
}

\begin{abstract}
A B S T R A C T
Keywords

Synergistic Interaction, Potyviruses, Maize Lethal Necrotic Disease, Maize.

\section{Article Info}

Accepted: 07 May 2016 Available Online: 10 June 2016

Synergistic interactions among pathogenic viruses are common in plants. Though not all, but a number of reported cases involving such interactions have a potyvirus partner during co-infection. The presence of the potyvirus group seems to favor its own multiplication on host and multiplication of a co-infecting partner. In this review, some characteristics favoring higher pathogenesis have been discussed using maize lethal necrosis (MLN)causing viruses namely Maize chlorotic mottle virus (MCMV) and its synergistic potyvirus, Sugarcane mosaic virus (SCMV). A comprehensive discussion on the role of potyvirus in the synergism has been presented to show that in MLN and similar synergisms - the machinery for induction, transmission and colonization of the host is catalysed by the potyvirus and not the co-infecting viral partner which otherwise seems to be the most virulent in the synergism-based diseases such as MLN disease in maize. Furthermore, the effect of MLN to food security and areas for future research for Africa has been discussed in this review.
\end{abstract}

\section{Introduction}

Synergistic diseases in plants have been described since late 1920s (Blood, 1928; Rochow and Ross, 1955; Garces-Orejuela and Pound, 1956; Lee and Ross, 1972; Kuhn and Dawson, 1973; Clark et al., 1980; Calvert and Ghabriel, 1983; Poolpol and Inouye, 1986; Uyemoto et al., 1981). There are two types of synergist interaction: the potyvirus-associated synergisms, in which one of the virus is a member of the potyvirus group and non-potyvirus synergisms, in which neither virus is a member of the same group. There is evidence to suggest that in many reported cases, a potyvirus group of plant viruses has been involved as one of the synergistic pair. 
For examples the interaction of Maize chlorotic mottle virus (MCMV) and a potyvirus such as Sugarcane mosaic virus (SCMV), Maize dwarf mosaic virus (MDMV) or Wheat streak mosaic virus (WSMV) (Hebert and Castillo, 1974; Uyemoto et al., 1981, Wangai et al., 2012 ); a potyvirus known as Sweet potato feathery mottle virus (SPFMV) with Sweet potato chlorotic stunt virus (SPCSV) (Kreuze, 2002); Bean pod mottle virus (BPMV) with a potyvirus known as Soybean mosaic virus (SMV) (Lee and Ross, 1972; Calvert and Ghabriel, 1983; Anjos et al., 1992) and the classic interaction of Potato virus $X$ (PVX) and a potyvirus: Potato virus $Y$ (PVY) (Goodman and Ross, 1974a; Goodman and Ross, 1974b; Vance, 1991).

This review describes weaponry machinery behind potyvirus synergism and how it influences its co-infecting partner in maize lethal necrosis (MLN) disease on maize and the effect of the disease in Africa. It is well known that MLN is caused by a synergistic co-infection with MCMV and a potyvirus such as MDMV, WSMV or SCMV (Goldberg and Brakke, 1987; Uyemoto et al., 1981, Wangai et al., 2012). MLN, also termed corn lethal necrosis (CLN) was first reported in Peru in 1973 (Hebert and Castillo, 1974) with losses of 10 and $15 \%$ in floury and sweet corn varieties. Yield reduction of up to $59 \%$ has been recorded in experimental plots (Castillo-Loayza, 1977). Later on in 1977, the disease was described in Kansas, United States of America causing losses of between $50 \%$ to $90 \%$ depending on the variety of maize and the season of the year (Niblett and Claflin, 1978). MLN was then reported in Nebraska (Doupnik, 1979), Hawaii (Jensen et al. 1990; Jiang et al., 1992), China (Xie et al., 2011), Kenya and Tanzania (Wangai et al., 2012), Uganda, Rwanda and Democratic Republic of Congo (Adams et al., 2014; Lukanda et al., 2014) and Ethiopia (Mahuku et al. 2015a). Since its first record in East Africa, MLN has spread and emerged as a threat to maize based food security in Sub-Saharan Africa (Mahuku et al., 2015b, Kiruwa et al., 2016).

Although causative agents of MLN have been well described, there is limited literature on the role played by the viral pathogens involved in the synergistic interaction that leads to MLN. Understanding the role of each individual virus particularly the potyviruses will improve the efforts towards controlling MLN including breeding for tolerance/resistance against the viruses and in developing an integrated crop and pest management options. Thus in this review, a comprehensive discussion on the role of such viruses in MLN disease development has been made as a guide in understanding a synergistic interaction in diseases development.

\section{The Infection Cycle by Plant Viruses}

The classical infection cycle of plant viruses includes entry into the cell, disassembly of the virus capsids, genome replication and transcription, and the translation of the viral RNA (Kasschau and Carrington, 2001). Resistance of maize plants to virus infection primarily owes to posttranscriptional gene silencing (PTGS). PTGS is a conserved sequence-specific RNA degradation mechanism in most eukaryotic organisms (Incarbone and Donoyer, 2013). It is often associated with methylation of the transcribed region of the silenced gene and with accumulation of small RNAs (21 to 25 nucleotides) homologous to the silenced gene (Molnár et al., 2005). In order for viruses to infect and cause disease in plants they have to suppress this gene silencing strategy. One strategy used by plant viruses to affect this silencing machinery is by 
expressing viral suppressors of RNA silencing (VSRs) at a multiple stages (Pumplin and Voinnet, 2013). Those VSRs are among a major requirement for successful colonization of the host plant by the virus. For viral infection to occur there must be cell-to-cell movement as well as long distance transport of the virus through vascular tissues, which requires one or more viral proteins that supply the dedicated movement functions (Syller, 2006). In the interaction between a potyvirus and MCMV, the main causative components of MLN, this dedicated movement function seems to be carried out by the potyvirus. In the recent study by Xia et al., (2016), the accumulations of both MCMV and MCMV-derived siRNAs in maize seemed to be higher during the synergistic infection (with SCMV and MCMV) compared to single infection. This implies that the presence of potyvirus was not only in favor of its own multiplication within the host but also catalyzing the multiplication of the partner co-infecting virus.

\section{Characteristics of MLN-causing Viruses}

MCMV from Tombusvirideae family is the only species in the genus Machlomovirus (King et al., 2011). It has an icosahedral particle with $30 \mathrm{~nm}$ in diameter and composed of a single $25 \mathrm{kDa}$ capsid protein subunit encapsidating $4.4 \mathrm{~kb}$ single-stranded positive-sense genomic RNA (Nutter et al., 1989; Lommel et al., 1991; Scheets 2004; Xie et al., 2010; ).

The MLN-causing potyviruses i.e. SCMV, WSMV or MDMV are single stranded, positive-sense RNA genome. They are characterized by induction of pinwheel or scroll-shaped inclusion bodies in the cytoplasm of the infected cells (Edwardson, 1974). These viruses contain a single large open reading frame $(\mathrm{ORF})$ in their genome that is translated into a single polyprotein, which is then autocatalytically digested into about 10 functional proteins: the first protein (P1), helper component proteinase (HC-pro), the third protein $(\mathrm{P} 3)$, the first $6 \mathrm{~K}$ protein (6K1), cylindrical inclusion protein (CI), the second $6 \mathrm{~K}$ protein $(6 \mathrm{~K} 2)$, viral genomelinked protein (VPg), nuclear inclusion a protein $(\mathrm{NIa})$, nuclear inclusion protein $\mathrm{b}$ (NIb) and coat protein (CP) (Gough et al., 1987; Guo et al.; Kreuze, 2002).

\section{The Role of Potyvirus in the Synergistic Interaction with MCMV}

The mechanism behind synergism between MCMV with a potyvirus is inconclusive in the literature. It is only known that, the region of the potyviral genome that mediates synergism encodes a polyprotein comprising of two potyviral gene products; P1 and HCPro, which are both multifunctional (Verchot et al., 1991; Verchot and Carrington, 1995; Brantley and Hunt, 1993). The HC-Pro of potyviruses is involved in viral vascular movement and suppression of an antiviral defense mechanism in plants (Savenkov and Valkonen, 2001). In synergism, the presence of one virus leads to the increased replication of another otherwise economically less important virus. For instance in the MLN, concentration of the potyvirus in the synergism is similar to that in a single infection whereas the concentration of MCMV is increased markedly (Xie et al., 2016). Two Potyvirus genes, the helper component gene and the gene for nuclear inclusion proteins are potentially avirulent in that they reduce the capacity of maize plants to inhibit the replication of MCMV (Rajamaki and Valkonen, 2009). HC-pro of potyviruses is known to enhace pathogenicity and accumulation of other heterogenous viruses (Pruss et al., 1997). However it is also clear 
that MLN induction is independent of the HC-Pro from a potyvirus WSMV, suggesting that this virus utilizes a gene other than HC-Pro to suppress PTGS and mediate synergistic interactions with MCMV (Stenger et al., 2007). Such argument provides a clear understanding that more factors are involved in the potyvirus-MCMV synergistic interaction. For instance, in the MLN saga, SCMV offers two proteins that aggravate MCMV replication and severity of symptoms: HCPro and nuclear inclusion protein-a and viral genome-linked protein (NIa/VPg) (Kreuze, 2002). SCMV VPg is known to interact with maize elongin $\mathrm{C}$ protein $(\mathrm{ZmElc})$ leading to its reduced production as detected in all maize organs, but most highly in leaves and pistil extracts (Zhu, et al., 2014). The reduction in the expression of $Z m E L c$ gene that produces ZmElc protein causes increased replication of MCMV. SCMV VPg is also believed to enhance cell to cell and long distance (systemic) movement of its own virus particles as well as those of MCMV (Barker, H. 1989; Cronin et al., 1995). The most important role of the potyvirusHC-pro though is to function in a counterdefensive capacity as a suppressor of PTGS (Kasschau and Carrington, 2001). Furthermore and in similarity with NIa/VPg, HC-Pro of the potyvirus SCMV interacts with ferredoxin-5 (FdV) of maize (Cheng et al., 2008) resulting into disturbance in its posttranslational import into maize bundlesheath cell (BSC) chloroplasts. Ferrodoxins play a key role in the distribution of electrons transferred from photosystem I of photosynthesis to a range of electron acceptors. In leaves under optimal conditions the majority of electron flux through ferrodoxins is used to reduce $\mathrm{NADP}^{+}$via a ferrodoxin NADP oxidoreductase (FNR). Of the three maize photosynthetic ferredoxin isoproteins (FdI, FdII and FdV), HC-Pro interacts specifically with FdV. The disruption of chloroplast function in maize due to concurrent infection by MCMV and SCMV leads to two things: (1) Production of less ATP required to drive the Calvin cycle through electron flow around photosystem I, which directly leads to low yield and (2) Inadequate production of chlorophyll and symptom expression.

\section{Transmission and Development of MLN}

Three main components are important for the MLN disease to occur; the viruses, vectors and a susceptible maize cultivar in a suitable environment (Redinbaugh and Zambrono-Mendoza 2014). For the virus to invade the host it must enter plant cell, replicate in primarily infected cell and move within cells i.e. cell to cell through plasmodesmata and long-distance (leaf to leaf) movement through the vascular system (phloem). Movement of viruses from cell to cell in plants involves one or more viral proteins with special functions. For instance, the case of MLN, the Potyviral HC-Pro has an N-proximal (100 aa) which not only controls virus transmission by aphid vectors but also virulence, genome amplification and virus accumulation. The HC-pro also has a central domain (200 aa) which affects long-distance movement and replicationmaintenance functions of the virus, and a Cproximal (150 aa) domains which is a cystein-type proteinase that plays a role in virus cell-to-cell movement (Cronin et al., 1995; Kasschau and Carrington, 2001; Syller, 2006). It thus seems doubtlessly that the presence of a potyvirus in the synergistic interaction is very important for development of the disease that seems to be primarily resulting from MCMV.

A model illustrating main stages in disease transmission and development on host is shown in Fig 1. Except for seed transmission 
(Jensen et al., 1991 and Zhang et al., 2011, Li et al 2011) where the viruses are carried by the seed, the illustration shown here mainly describes other means of viral transmission. Thus, in this model, insect vectors or other viral reservoirs introduce the viruses into plant cell. Penetration of viruses into non-infected plant cells takes place in wounds created by the feeding insect vectors or in other openings in plants including those caused by mechanical injury by human activities. Some insects vectors such as viruliferous beetles spread a layer of pre-digestive materials known as regargitant on host leaves and deposit virus particles in the wound at the feeding site (Trigiano et al., 2008). The deposited virus removes the protein coat and nucleic acid enters the nuclear membrane and alters the host DNA replication process by changing its RNA to complementary DNA (cDNA) to mimic its host maize DNA so as to produce many of its copies. When more copies of viral particles have been created, they can move between cells through plasmadermata and the whole maize plant through phloem then colonizes a susceptible host. In a resistant host, the virus colonization cannot be possible thus no MLN symptoms.

Brault et al., (2010) indicated that Maizeinfecting potyviruses can be transmitted in a non-persistent manner by about 25 aphid species. Seed transmission of SCMV is possible at a rate of 0.4 to $3.9 \%$ depending on the genotype (Li et al., 2011). Potyviruses cause mosaic symptoms and dwarfing in susceptible maize cultivars.

The main vectors identified through experiments which can transmit MCMV in a semi-persistent manner include Chrysomelid beetles including Diabrotica species (Nault et al., 1978), maize thrips (Frankliniella williamsi) and western flower thrips (F.occidentialis) (Cabanas et al., 2013; Zhao et al., 2014). Mahuku et al., (2015b) indicate that there are possibilities that other vectors among thrips, beetles or others insects that are associated with maize can transmit MCMV. Further research is needed to find out whether or not other insects commonly found in maize can transmit MCMV. Seed transmission of the virus is inconclusive. Earlier report by Jensen et al., (1991) indicated a rate ranging from $0 \%$ to $0.33 \%$ for MCMV in 17 lots of maize seed originating from MCMV-infected plant. In a recent study by Mahuku et al.,( 2015b), 72\% of seeds (18 out of 25 seeds) originating from MCMV-infected maize plants and 12 out of 26 ten seed samples pooled from 26 lots of locally purchased seeds were positive with real time polymerase chain reaction (RT-PCR). However, further research is needed to find out whether contaminated seeds can transmit MCMV to progenies. MCMV causes chlorotic mottling to severe mosaic stunting, premature plant death, yellowing and necrosis, sterility of male flowers and shortened, malformed, and partially filled ears depending on developmental stage at the time infection, prevailing environmental condition and genetic background (Wangai et al., 2012, Mahuku et al., 2015a).

\section{Effect of MLN Symptoms on Host}

MLN has been identified as the most devastating foliar disease responsible for highest yield loss in maize (Ochieng et al., 2012). The two catch terms; 'lethal' and 'necrosis' describes two conditions. The first portrays a disease that 'kills infected plant' and the second term 'necrosis' means a disease which 'seriously kills infected cells'. If the viral pathogens succeed to colonize the host (Fig 1), MLN disease symptoms can develop. Most of the developed symptoms have direct effect to plants growth and development (Table 1). Main symptoms 
incited by MLN-interacting viruses in a susceptible host include; yellow streaks parallel to leaf veins, chlorotic mottling, leaf necrosis which, may lead to "dead heart" symptom and plant death, premature aging of the plants (Gordon et al., 1984), sterility in male plants and failure to tassel, malformed or no ears, rotting of cobs and failure of cobs to put on grains and (Nelson et al., 2011; Wangai et al., 2012,; Makone et al., 2014).

\section{Potential Impact of MLN on Food Security}

MLN is expected to threaten maize production especially in developing countries. We know that, maize is ranked the third most important cereal crop after wheat and rice (Khalili et al., 2013) and that more than 1.2 billion small scale farmers in Latin America and Sub-Saharan Africa depend on it as their main staple food and livestock feed (Iken \& Amusa, 2004, Onasanya et al., 2009). It has been estimated that highly MLN-affected areas can experience a massive yield loss (Wangai et al., 2012). Due to dependence of farmers to maize as their main food crop, shortage in its supply can be synonymous with food insecurity. The potential risk of MLN in Africa is high. Considering each individual MLN-causing viruses, Mahuku et al., (2015b) indicated that MCMV is considered a primary disease-causing virus behind almost all MLN cases. The MCMV alone has a big potential to establish in warm arid, semi arid and sub-humid tropics (Isabirye and Rwomushana, 2016).

Of the identified potyviruses, MDMV and SCMV are wide spread and cause diseases in maize worldwide (Mahuku et al., 2015b). Their widely presence can be indicate their adaptation to their interaction to host plants in areas where MCMV is considered new.
Since they are adapted, they have a fully machinery to attack the host, and the host has ways of resisting attack from the virus (Redinbaugh and Zambrano 2014). Since MCMV is new to the crop system, plants seems not to be prepared for attack i.e. plants have little or lacks resistance to the pathogen, and thus the additional weakened effect by the potyviruses or other viruses such as Maize mosaic virus and Maize rayado fino virus and/or abiotic stress favor their full colonization to maize host (Nelson et al., 2011). As no single germplasm has been identified as resistant to the synergistic-interacting viruses as whole, serious maize loses are expected in Africa, for instance, estimates made with an ecological niche models using a genetic algorithm (GARP) by Isabirye and Rwomushana (2016) show showed that, suitable habitats for MCMV is as high as $662,974 \mathrm{~km}^{2}$ in Ethiopia, 625,690 $\mathrm{km}^{2}$ in Tanzania, $615,940 \mathrm{~km}^{2}$ in D. R. Congo, $361,556 \mathrm{~km}^{2}$ in Angola, 298,402 $\mathrm{km}^{2}$ in South Africa and 265,564 $\mathrm{km}^{2}$ in Madagascar. Swaziland, Burundi, and Rwanda will lose $100 \%$ each and Uganda $88.1 \%$ in terms of national maize production area. In a synergistic interaction of MCMV with a potyvirus, higher damage to maize crop are expected as it is clear that effects are higher when in combination compared to when MCMV or a potyvirus infects the host individually (Xia et al., 2016).

\section{Management of MLN}

Some management principles such as plant quarantine, pathogen eradication, avoidance, plant protection and use of plant resistance has been reviewed by Kiruwa et al. (2016). In Africa where MCMV is considered new, scarce information is available on management of MLN. In other countries such as Hawii, integration of cultural practice, host tolerance and suitable 
insecticides has been used (Nelson et al., 2011). Work in developing suitable management options such as screening for MLN-tolerant/resistant germplasm and vector control is going on in countries heavily attacked by MLN in Africa (Mahuku et al., 2015b).

\section{Conclusion and Future Research Needs}

In conclusion, this paper discussed the role of potyvirus during its synergism interaction with its co-infecting partner MCMV. It seemed interestingly that in such synergisms, the potyvirus is likely to possess important mechanism for enhanced infection by the co-infecting partner virus which is viewed as the primary disease behind MLN development. One of important proteins playing a significant role in the potyvirus infectivity is the HC-pro, which is multifunctional and possesses counterdefensive capacity to suppress the PTGS of the host. In the synergistic interaction with SCMV and MCMV, the accumulations of both MCMV and MCMV-derived siRNAs in maize is reported to be increased remarkably compared to single infection implying that the presence of potyvirus was not only in favor of its own multiplication within the host but also catalyzing the multiplication of the partner co-infecting virus.

Table.1 Effect of MLN symptoms on host

\begin{tabular}{|l|l|l|}
\hline No & Symptom & Effect \\
\hline 1 & Chlorosis & Plant has insufficient photosynthesis \\
\hline 2 & Premature aging & Plant receives insufficient heat units required for grain filling \\
\hline 3 & Necrosis & reduces total number of photosynthetic cells of the leaf \\
\hline 4 & Sterility of male flowers & $\begin{array}{l}\text { Leads to infected plants having barren; having small or } \\
\text { deformed ears and which set little or no seed. }\end{array}$ \\
\hline 5 & Dying of plant & Total plant failure to reach maturity \\
\hline
\end{tabular}

Fig.1 A model describes four stages (A-D) of virus synergistic infection on a host plant. A: Virus reservation stage., B: Invasion stage., C: Multiplication and establishment on host and D: Colonization stage. In stage A., vector(s) or other virus reservoir carries the viruses before it becomes in contact with the host then., in stage B., the viruses i.e. MCMV., part (i) and/or a potyvirus part (ii) are transmitted unto the host plant cell where they multiply and establish in a susceptible host (stage C). In stage D., the viruses fail to colonize a resistant host., part (i) or succeed to colonize the host and develop MLN symptoms in a susceptible host., part (ii).

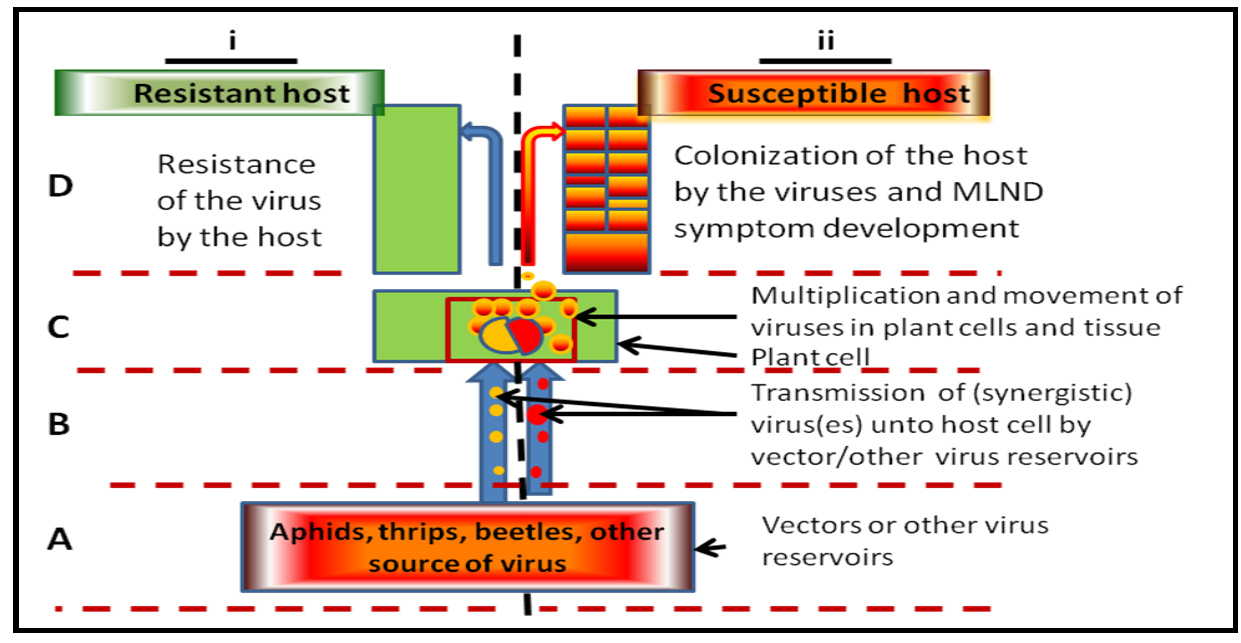


This observation is lightening a way towards developing MLN-resistant maize varieties. The genetics of maize resistance against MDMV and other potyviruses has been described (Jones et al., 2007; Redinbaugh and Pratt, 2009; Redinbaugh and Zambrano, 2014). There is need to use such information in initiating marker assisted breeding to halt MLN in areas where maize is the most important crop such as most African countries including Tanzania, Kenya, Rwanda, DRC, Ethiopia and Uganda where MLN has been reported. Though there is no maize genotypes reported to be resistant to MCMV, some tolerant lines have been developed (Redinbaugh and Zambrano, 2014). We know that there is potential for transgenic resistance against MCMV (Murry et al., 1993). This potential could also be determined. Since abiotic/environmental stress can exacerbate MCMV infections, there is need to explore environmental conditions and molecular mechanisms behind vector-host-virus interactions to guide designing the MLNresponse strategies.

\section{Acknowledgements}

The authors acknowledge the Agricultural Research Institutes - Eastern Zone-Ilonga, Kilosa Morogoro and Southern ZoneUyole, Mbeya; Northern Zone-Selian, Arusha; Tropical Pesticides Research Institute (TPRI), Arusha; Sokoine University of Agriculture, Morogoro and The Nelson Mandela African Institution of Science and Technology, Arusha for their services and support during development of this review.

\section{References}

Adams, I.P., Harju, V.A., Hodges, T., Hany, U., Skelton, A., Rai, S., Daka, M.K., Smith, J., Fox, A., Uzayisenga, B., Ngaboyisonga, C., Uwumukiza, B.,
Rutikanga, A., Mutherford, M., Ricthis, B., Phiri, N., Boonham, N. 2014. First report of maize lethal necrosis disease in Rwanda. New Disease Reports, 29: 22.

Anjos, J.R., Jarlfors, U., Ghabrial, S.A. 1992. Soybean mosaic virus (potyvirus) enhances the titer of two comoviruses in dually infected soybean plants. Phytopathol., 82: 1022-1027.

Barker, H. 1989. Specificity of the effect of sap-transmissible viruses in increasing the accumulation of luteoviruses in co-infected plants. Annals of Appl. Biol., 115: 71-78.

Blood, H.L. 1928. A "streak" of tomatoes produced by a disturbing principle from apparently healthy potatoes in combination with tomato mosaic virus. Phytopathol., 18: 311-315.

Brantley, J.D., Hunt, A.G. 1993. The Nterminal protein of the polyprotein encoded by the potyvirus tobacco vein mottling virus is an RNAbinding protein. J. General Virol., 74: 1157-1162.

Brault, V., Uzest, M., Monsion, B., Jackuot, E., Blanc, S. 2010. Aphid as transport devices for plant viruses. Comptes Rendus Biologies, 333: 524-538.

Cabana, D., Watanabe, S., Higashi, C.H.V., Bressan, A. 2013. Dissecting the mode of Maize chlorotic virus (Tombusvidae: Machlomovirus) transmission by Franliniella williamsi (Thysanoptera: Thripidae). J. Economical Entomol., 106: 16-24.

Calvert, L.A., Ghabrial, S.A. 1983. Enhancement by soybean mosaic virus of bean pod mottle virus titer in doubly infected soybean. Phytopathology 73: $992-$ 997.

Castilo, J., Hebert, T.T. 1974. New Virus Diseases Affecting Corn in Peru 
(Nueva enfermedad virosa affectando al maiz en al Peru) Fitopathol., 9: 7984.

Cheng, Y.Q., Liu, Z.M., Xu, J., Zhou, T., Wang, M.., Chen, Y.T., Li, H.F., Fan, Z.F. 2008. HC-Pro protein of Sugar cane mosaic virus interacts specifically with maize ferredoxin-5 in vitro and in planta. J. General Virol., 89(8): 2046-54.

Clark, R.L., Hill, J.H., Ellis, M.D. 1980. Tomato scorch, a new virus disease of tomatoes. Phytopathol., 70: 131-134.

Cronin, S., Verchot, J., Haldeman-Cahill, R., Schaad, M.C., Carrington, J.C. 1995. Long-distance movement factor: a transport function of the potyvirus helper component proteinase. Plant Cell, 7(5): 549-559.

Edwardson, J.R. 1974. Some properties of the potato virus Y-group. Florida Agricultural Experimental Station Monograph Series 4, 225 pp.

Garces-Orejuela, C., Pound, G.S. 1956. The multiplication of tobacco mosaic virus in the presence of cucumber mosaic virus or tobacco ringspot virus in obacco. Phytopathology 47: 232239.

Goldberg, K., Brakke, M.K. 1987. Concentration of Maize chlorotic mottle virus increased in mixed infections with Maize dwarf mosaic virus., strain B. Phytopathology 77: 162-167.

Goodman, R.M., Ross, A.F. 1974a. Enhancement of potato virus $\mathrm{X}$ synthesis in doubly infected tobacco occurs in doubly infected cells. Virol., 58: $16-24$.

Goodman, R.M., Ross, A.F. 1974b. Enhancement of Potato virus $X$ synthesis in doubly infected tobacco occurs in doubly infected tobacco depends on the timing of invasion by the viruses. Virol., 58: 263-271.
Gough, K.H., Azad, A.A., Hanna, P.J., Shukla, D.D. 1987. Nucleotide sequence of the capsid and nuclear inclusion protein genes from the Johnson grass strain of Sugarcane mosaic virus RNA. J. General Virol., 68: 297- 304.

Guo, J., Gao, S., Lin, Q., Wang, H., Que, Y., $\mathrm{Xu}$, L. 1992. Transgenic Sugarcane Resistant to Sorghum mosaic virus based on coat protein gene silencing by RNA interference. BioMed Research International Hindawi Publishing Corporation Volume 2015, Article ID 861907, 9 pages. http://dx.doi.org/10.1155/2015/86190 7.

Herbert, T.T., Castilo, J. 1973. A new Virus Disease of Maize in Peru Abstract in $2^{\text {nd }}$ International Congress Plant Pathology. 72 Minneapolis., USA.

Iken, J.E., Amusa, N.A. 2004. Maize research and productivity in Nigeria. African J. Biotechnol., 36: 302-307.

Incarbone, M., Dunoyer, P. 2013. RNA silencing and its suppression: novel insights from in planta analyses. Trends Plant Sci., 18: 382392.

Isabirye, B.E., Rwomushana, A. 2016. Current and future potential distribution of maize chlorotic mottle virus and risk of maize lethal necrosis disease in Africa, J. Crop Protection, 52: 215-228.

Jensen, S., Wysong, D., Ball, E., Higley, P. 1991. Seed transmission of maize chlorotic mottle virus. Plant Dis., 75(5): 497-498.

Jensen, S.G., Ooka, J.J., Lockhart, B.E., Lommel, S.A., Lane, L.C., Wysong, D.S., Doupnik, B. 1990. Corn lethal necrosis in Hawaii. Phytopathol., 80: 1022.

Jones, M.W., Redinbaugh, M.G., Louie, R. 2007. The Mdml locus and maize 
resistance to Maize dwarf mosaic virus. Plant Dis., 91: 185-190.

Kasschau, K.D., Carrington, J.C. 2001. Long-distance movement and replication maintenance functions correlate with silencing suppression activity of potyviral HC-Pro. Virol., 285(1): 71- 81.

Khalili, M., Naghavi, M.R., Aboughadareh, A.P., Rad, H.N. 2013. Effects of Drought Stress on Yield and Yield Components in Maize cultivars Zea mays L.., Int. J. Agronomy and Plant Production, 44: 809-812.

King, A.M.Q., Lefkowitz, E., Adams, M.J., Carstens, E.B. 2011. Virus Taxonomy: Ninth Report of the International Committee on Taxonomy of Viruses. Elsevier Academic Press, San Diego, CA: 256267.

Kiruwa, F.H., Feyissa, T., Ndakidemi, P.A. 2016. Isights of maize lethal necrotic diseases: A major constraint to maize production in East Africa. African J. Microbiol. Res., 10(9): 271-279.

Kreuze, J.F. 2002. Molecular studies on the sweet potato virus disease and its two causal agents. Doctorís dissertation. ISSN 1401-6249., ISBN 91-5766180-4.

Kuhn, C.W., Dawson, W.O. 1973. Multiplication and pathogenesis of cowpea chlorotic mottle virus and southern bean mosaic virus in single and double infections in cowpea. Phytopathol., 63: 1380-1385.

Lee, Y.S., Ross, J.P. 1972. Top necrosis and cellular changes in soybean doubly infected by soybean mosaic and bean pod mottle viruses. Phytopathol., 62: 839-845.

Li, L., Wang, X.F., Zhou, G.H. 2011. Effects of seed quality on proportion of seed transmission of sugarcane mosaic virus in maize. Cereal
Research Communication 39:257266.

Lommel, S., Kendall, T., Xiong, Z., Nutter, R. 1991. Identification of the maize chlorotic mottle virus capsid protein cistron and characterization of its subgenomic messenger RNA. Virol., 181(1): 382-385.

Lukanda, M., Owati, A., Ogunsanya, P., Valimunzigha, K., Katsongo, K., Ndemere, H., Kumar, L.P. 2014. First report of Maize chlorotic motle virus infecting maize in the Democratic Republic of Congo. Plant Dis., 98:1448-1449.

Mahuku, G., Lockhart, B.E., Wanjala, B., Jones, M.W., Kimunye, J.N., Stewart, L.R., Cassone, B.J., Sevgan, S., Nyasan, J.O., Kusia, E., Kumar, P.L., Niblett, C.L., Kiggundu, A., Asea, G., Pappu, H.R., Wangai, A., Prasanna, B.M., Redinbaugh, M.G. 2015 b. Maize Lethal Necrosis MLN, an emerging threat to Maize-based food security in Sub-Saharan Africa. Phytopathol., 105(7): 956-965

Mahuku, G., Wangai, A., Sadessa, K., Teklemold, A., Wegary, D., Ayalneh, D., Adams, I., Smith, J., Bottomley, E., Bryce, S., Braidwood, L., Feyissa, B., Regassa, B., Wanjala, B., Kimunye, N., Mugambi ,N., Monjero, K., Prasanna, M. 2015a. First Report of Maize chlorotic mottle virusand Maize Lethal Necrosis on Maize in Ethiopia. Plant Dis., 99(12): 1870

Makone, S.M., Menge, D., Basweti, E. 2014. Impact of Maize Lethal Necrosis Disease on maize yield: A Case of Kisii, Kenya. International $J$. Agrictural Extension, 23: 211-218.

Molnár, A., Csorba, T., Lakatos, L., Varallyay, E., Lacomme, C.,Burgyan, J. 2005. Plant virusderived small interfering RNAs originate predominantly from highly 
structured single-stranded viral RNAs. J. Virol., 79: 7812-7818.

Murry, L.E., Elliott, L.G., Capitat, S.A., West, J.A., Hanson, K.K., Scarafia, L., Johnstone, S., Delucaflaherty, C., Nichols, S., Cunana, D., Dietrich, P.S., Mettler, I.J., Dewald, S., Warnick, DA., Rhodes ,C., Sinibaldi, R.M., Brunke ,K.J.1993. Transgenic corn plants expressing MDMV strain$\mathrm{B}$ coat protein are resistant to mixed infections of maize-dwarf mosaicvirus and maize chlorotic mottle virus. Bio-Technology 11:1559-1569

Nault, L., Styer, W., Coffey ,M., Gordon, D., Negi, L., Niblett, C. 1978. Transmission of maize chlorotic mottle virus by chrysomelid beetles. Phytopathol., 68(7): 10711074.

Nelson, S., Brewbaker, J., Hu1, J. 2011. Maize Chlorotic Mottle. University of Hawaii. Plant Dis., 79: 6.

Niblett, C., Claflin, L.E. 1978. Corn Lethal Necrosis a new Virus Disease of Corn in Kansas. J. Plant Dis., 62: 15-19.

Nutter, R.C., Scheets, K., Panganiban, L., Lommel ,S. 1989. The complete nucleotide sequence of the maize chlorotic mottle virus genome. Nucleic Acids, 178: 3163 3177.

Ochieng, J., Wangai, A., Miyogo, S., Karanja, T., Oduor H. Kimani E. Irungu J., Sikinyi E., Kinyua Z., Ngaruiya P., Ligeyo D and Kipkemboi S., 2012. "Status of maize lethal necrosis disease and general maize performance" stakeholders' maize tour Dates: 2nd to 12th July., 2012 report: pp 1-34.

Onasanya R.O., Aiyelari O.P., Onasanya A., Oikeh S., Nwilene F.E and Oyelakin O.O., 2009. Growth and Yield Response of Maize Zea mays L. to Different Rates of Nitrogen and
Phosphorus Fertilizers in Southern Nigeria. World Journal of Agricultural Sciences 5 (4): 400 -407. Poolpol P and Inouye T., 1986. Enhancement of cucumber mosaic virus multiplication by zucchini yellow mosaic virus in doubly infected cucumber plants. Annals of Phytopathological Society of Japan 52: 22-30.

Pruss G., Ge X., Shi X.M., Carrington J.C and Bowman-Vance V., 1997. Plant viral synergism: the potyviral genome encodes a broad-range pathogenicity enhancer that transactivates replication of heterologous viruses. Plant Cell 9: 859-868.

Pumplin N and Voinnet O., 2013. RNA silencing suppression by plant pathogens: defence., counter-defence and counter-counter-defence. Nature Reviews Microbiology 11:745-760.

Rajama M and Valkonen J.P.T., 2009. Control of nuclear and nucleolar localization of nuclear inclusion protein a of Picorna-like Potato virus Ain Nicotiana species. The Plant Cell 21: 2485-2502.

Redinbaugh M and Pratt R. C., 2009. Virus resistance. In Handbook of maize: Its biology., eds. J. L. Bennetzen., S. C. Hake., 251-268. New York: Springer.

Redinbaugh M.G and Zambramo-Mendoza J.L., 2014. Control of virus in maize. Advances in Virus Research 90:391429.

Rochow W.F and Ross A.F., 1955. Virus multiplication in plants doubly infected by potato viruses $\mathrm{X}$ and Y. Virology 1:10-27.

Savenkov E.I and Valkonen J.P.T., 2001. Potyviral Helper-Component Proteinase Expressed in Transgenic Plants Enhances Titers of Potato Leaf Roll Virusbut Does Not Alleviate Its 
Phloem Limitation. Virology 283(2):285-293.

Scheets K., 2004. Maize chlorotic mottle virus. In Viruses and Virus Diseases of Poaceae Gramineae. Lapierre., H. and Signoret., P. eds. Institut National de la Rocherche Agronomique., Paris pp. 642-644.

Stenger D.C., Young B.A., Ou F., Morris T.J and French R., 2007. Wheat streak mosaic virus Lacking Helper Component-Proteinase Is Competent to Produce Disease Synergism in Double Infections with Maize chlorotic mottle virus. Virology 9710: 1213-1221.

Trigiano, R.N., Windham, M.T., Windhan, A.S., Eds., 2008. Plant pathology, concepts and laboratory exercises. CRC Press 21:269.

Uyemoto, J.K., Claflin, L.E., Wilson, D.L., Raney, R.J. 1981. Maize chlorotic mottle and maize dwarf mosaic viruses: Effect of single and double inoculations on symptomology and yield. Plant Dis., 65: 39-41.

Vance, V.B. 1991. Replication of potato virus $\mathrm{X}$ RNA is altered in coinfections with potato virus $\mathrm{Y}$. Virol., 182: 486-494.

Verchot, J., Carrington, J.C. 1995. Evidence that the potyvirus $\mathrm{P} 1$ proteinase functions in trans as an accessory factor for genome amplification. $J$. Virol., 69: 3668-3674.

Verchot, J., Koonin, E.V., Carrington, J.C. 1991. The 35-kDa protein from the N- terminus of the potyviral polyprotein functions as a third virus-encoded proteinase. Virol.,185: 527-535.

Wangai, A.W., Redinbaugh, M.G., Kinyua, Z.M., Miano, D.W., Leley, P.K., Kasina, M., Mahuku, G., Scheets, K., Jeffers, D. 2012. First Report of Maize chlorotic mottle virus and Maize lethal necrosis in Kenya. Disease Notes, 96(10): 1582.

Xia, Z., Zhao, Z., Chen, L., Li, M., Zhou, T., Deng, C., Zhou, .,d Fan, Z. 2016. Synergistic infection of two viruses MCMV and SCMV increases the accumulations of both MCMV and MCMV-derived siRNAs in maize . Scientific Reports 6. Article number 20520. Doi: $10.1038 /$ srep20520.

Xie, L., Zhang, J., Wang, Q., Meng, C., Hong, J., Zhou, X. 2010., Characterization of Maize Chlorotic Mottle Virus Associated with Maize Lethal Necrosis Disease in China. $J$. Phytol., 159(3): 191-193.

Zhang, Y., Zhao, W., Li, M., Chen, H., Zhu, S., Fan, Z. 2011. Real-time Taqman RT-PCR for detection of maize chlorotic mottle virus in maize seeds. J. Virol. Methods, 1711: 292294.

Zhao, M., Ho, H., Wu, Y., He, Y., Li, M. 2014. Western flower thrips (Frankliniella accidentalis) transmits Maize chlorotic mottle virus. $J$. Phytopathol., 162: 532-536.

\section{How to cite this article:}

Mbega, E.R., P.A. Ndakidemi, D.P. Mamiro, A.A. Mushongi, K.M. Kitenge and Ndomba, O.A. 2016. Role of Potyviruses in Synergistic Interaction Leading to Maize Lethal Necrotic Disease on Maize. Int.J.Curr.Microbiol.App.Sci. 5(6): 85-96. doi: http://dx.doi.org/10.20546/ijcmas.2016.506.011 